\title{
sciforum
}

Conference Proceedings Paper

\section{Preservation of the cultural heritage from floods using the numerical code Iber}

\author{
José González-Cao 1, *, Orlando García-Feal ${ }^{2}$, Luis Cea ${ }^{3}$, and Moncho Gómez-Gesteira ${ }^{4}$ \\ Published: 06/11/2017 \\ Academic Editor: Raquel Nieto \\ 1 Environmental Physics Laboratory (EPHYSLAB), Universidade de Vigo, Campus As Lagoas s/n, 32004, \\ Orense, Spain; jgcao@uvigo.es \\ 2 Environmental Physics Laboratory (EPHYSLAB), Universidade de Vigo, Campus As Lagoas s/n, 32004, \\ Orense, Spain; orlando@uvigo.es \\ 3 Environmental and Water Engineering Group, Departamento de Ingeniería Civil, Universidade da \\ Coruña, Campus Elviña s/n, Coruña, España: luis.cea@udc.es \\ 4 Environmental Physics Laboratory (EPHYSLAB), Universidade de Vigo, Campus As Lagoas s/n, 32004, \\ Orense, Spain; mggesteira@uvigo.es
}

* Correspondence: jgcao@uvigo.es; Tel.: +34-988-372-255

\begin{abstract}
Preserving the cultural heritage of antiquity is one of the most important tasks of the mankind. On this basis, the European Parliament, via the Policy Department Structural and Cohesion Policies, published the study entitled: "Protecting The Cultural Heritage From Natural Disasters". This study analyses the actions that are being carried out to protect the cultural heritage from floods, earthquakes and other natural phenomena in Europe. In this work the numerical code Iber has been used to design the protection barriers from floods of the Roman Military Camp of "Aquis Querquennis" (69-79 A.C.). This Roman Camp, inside the Roman Itinerary "Via Nova", is located in the shore of the "Las Conchas" impoundment in the Northwest of Spain. This Camp is subjected to the floods associated to this impoundment of "Las Conchas". Therefore, and according to the directives of the European Parliament, a series of protecting measures have been analysed using Iber, which is a numerical code that uses the finite volume scheme to solve the 2-D Shallow Water Equations.
\end{abstract}

Keywords: Cultural Heritage; Antiquity; Conservation; Floods; Numerical Simulation; Iber.

\section{Introduction}

One of the greatest threats to cultural heritage of antiquity is derived from natural disasters such as floods, earthquakes, volcanoes, among others. The number of natural disasters and their cost for both goods and people have increased during the last decades [1]. Therefore, with this in mind, the European Parliament's Committee on Cultural and Education commissioned the study Protecting the cultural heritage from natural disaters [2]. This study examines the instruments and activities implemented by some European countries in order to protect cultural heritage from different types of natural disasters. Floods are considered one of the most frequent natural disasters and their impact in urbanized territories have increase over last decades within a context of climate change. The effects derived from floods vary both in extent and duration ranging from local to international impact. Different types of damage are derived from floods: static/dynamic loads, impacts from floating 
bodies or wetting of materials. Rising sea level is another problem associated to floods also related to climate change. The current forecasts of the sea level increase are not completely valid, so the flood barriers designed with these forecasts may be ineffective.

One of the most quite dangerous floods for cultural heritage are the so-called flash floods. These types of floods are characterized by a rapid increase of the water level associated to peak flows derived from extreme rainfall events. Usually the prevention and emergency measures applied to increase the safety of persons are not adequate to protect cultural heritage assets [3]. This inadequate protection is due to the lack of knowledge of these assets and the complexity to calculate their value due to their non-market nature [4]. A series of mistakes in the protection of cultural heritage can be found in [5].

The North-west of Spain, specifically the province of Orense (Autonomous Community of Galicia), is a region where the combination of the cultural heritage assets and floods derived from rainfall events or construction of impoundments is well documented. One of the most important historical assets in the NW of Spain is the Roman Military Camp of "Aquis Querquennis". Figure 1 shows the location of the Camp "Aquis Querquennis". This military establishment was constructed in the years 69-79 A.C. as a component to control of the "Via Nova" that connected the Portuguese city of Braga with the Spanish village of Astorga. The total surface of the Camp was near 25,000 square meters and it was occupied by more than 500 legionaries of the III cohort of the Legion VII Gemina that were displaced to the Dacia (Bulgary) after the Camp was abandoned in the years 98117 A.C. during the reign of spanish emperor Trajano. The Camp was consisted of six main components: principia (general barracks), strigia (bunkhouses of the troop), horrea (granaries), valetudinarian (hospital), inner roads and systems of drainage and defences (wall, towers, doors, intervallum and pitt). All this underlines the great importance of this roman Camp. Nowadays this campament is located in the shore of the "Las Conchas" impoundment and it is usually drowned during rainy season. Figure 2 shows and aerial image of the "Las Conchas" impoundment and a detailed aerial image of the Roman Camp "Aquis Querquennis".

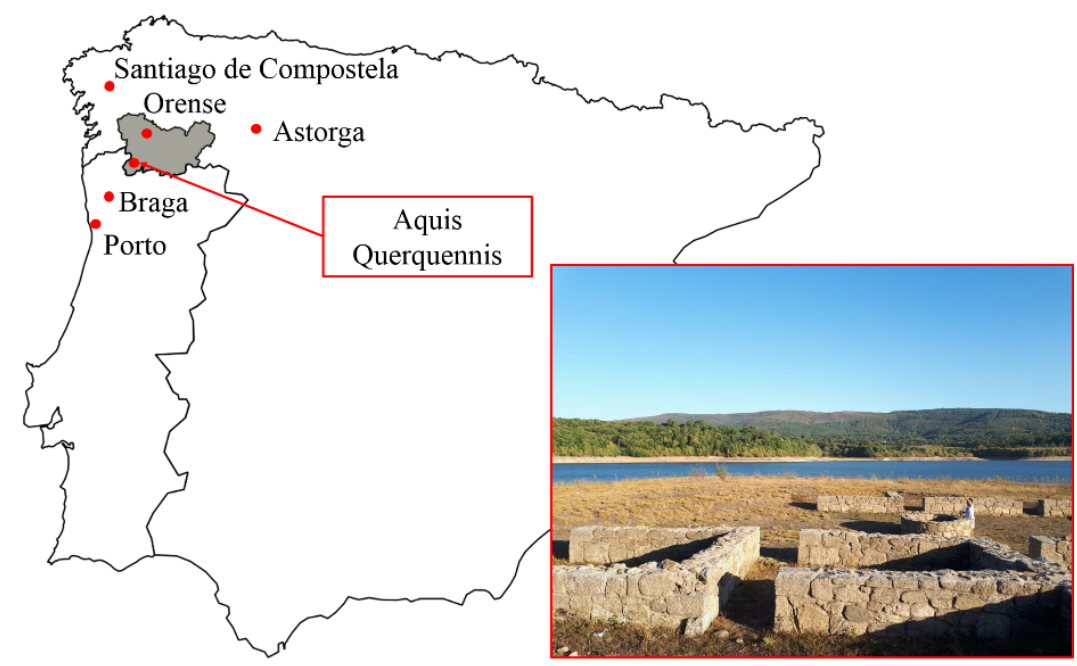

Figure 1. Location of the Roman Military Camp "Aquis Querquennis" with the main cities near the Camp marked with red points. The province of Orense corresponds with the shaded area. A detail of the Roman Camp is also shown. 
The 1st International Electronic Conference on Hydrological Cycle (CHyCle-2017), 12 - 16 November 2017; Sciforum Electronic Conference Series, Vol. 1, 2017

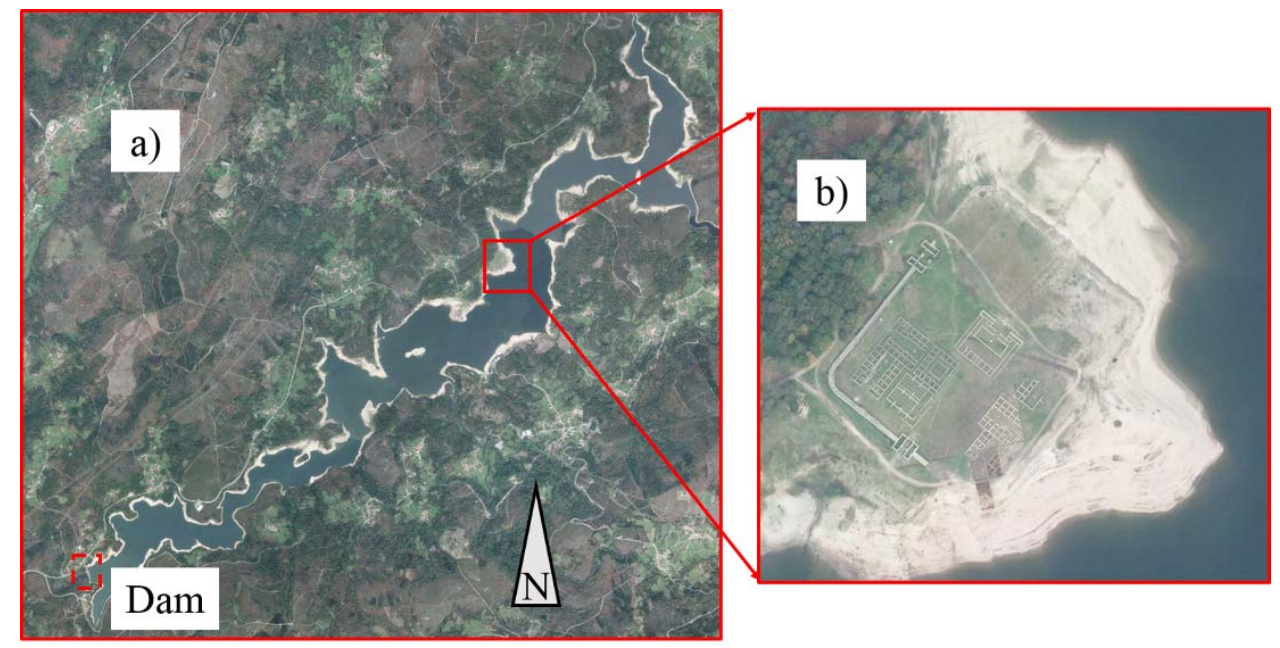

Figure 2. Aerial image of "Las Conchas" impoundment (a) and a detailed aerial image of "Aquis Querquennis" (b) (Images PNOA courtesy of @ Instituto Geográfico Nacional).

\section{Area under scope}

"Las Conchas" impoundment (figure 2) is located in NW of Spain near the Portuguese border. According to [6], this impoundment was constructed in 1949 for the main purposes of energy generation and recreation activities in "Limia" river. The watershed associated to this reservoir covers an area of $978 \mathrm{~km}^{2}$. The total area of the reservoir is equal to $6.31 \mathrm{~km}^{2}$ with a capacity near of $72 \mathrm{hm}^{3}$. The elevation of the dam crest is 549 m.a.s.l. and it is $505 \mathrm{~m}$ long. The dam has one spillway operated by gates with an outflow capacity (design outflow) of $900 \mathrm{~m}^{3} / \mathrm{s}$. Figure 3 shows an image of the dam associated to "Las Conchas" impoundment.

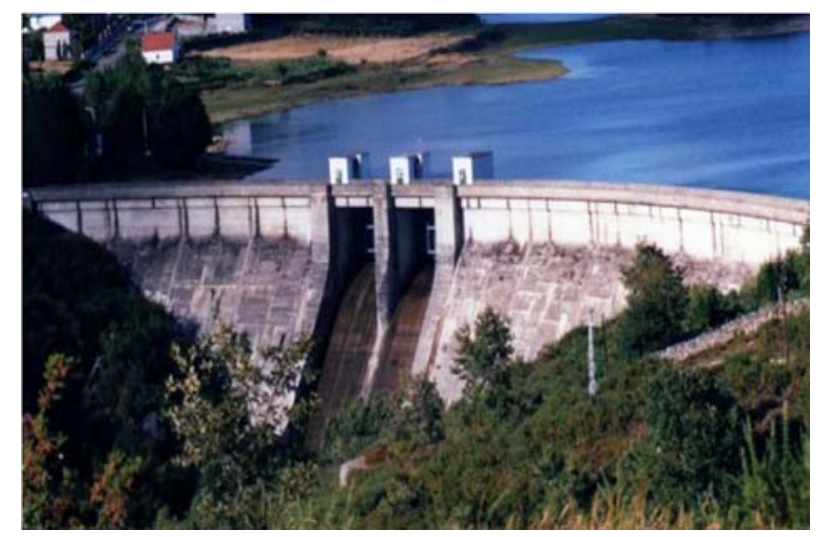

Figure 3. Dam associated to "Las Conchas" impoundment.

\section{Numerical model}

The numerical model used to analyse floodings in the Roman Campament "Aquis Querquennis" is Iber [7] developed by GEAMA (Universidade da Coruña) and Flumen (Universitat Politècnica de Catalunya) that can be freely downloaded from [8]. Iber solves the Saint Venant Equations in 2D (equation 1) by means of a finite volume scheme. The model has been widely applied to analyse flooding problems. The reader can obtain a detailed explanation of this type of problems in [9] and [10].

In equation (1) $h$ refers to the water depth, $U_{x}$ and $U_{y}$ are horizontal components of the velocity of the flow, $g$ is the acceleration of gravity, $Z_{b}$ is elevation of the bottom of the channel, $\rho$ is the density of the water, $\tau_{s, x}$ and $\tau_{s, y}$ are the friction derived from the wind in the $x$ and $y$ directions, $\tau_{b, x}$ and $\tau_{b, y}$ 
The 1st International Electronic Conference on Hydrological Cycle (CHyCle-2017), 12 - 16 November 2017;

Sciforum Electronic Conference Series, Vol. 1, 2017

are the friction in bottom of the channel in the $\mathrm{x}$ and $\mathrm{y}$ directions and $v_{t}$ is the turbulent viscosity. The assumptions of the 2D Saint Venant Equations are:

- The velocity vector only varies in the horizontal direction of the flow. The vertical component is not considered;

- The slopes of the bottom are small;

- No erosion is considered;

- Density of water is considered as a constant value;

- The flow is considered as incompressible.

which are usually fulfilled in rivers, tidal estuaries or impondments

$$
\left\{\begin{array}{l}
\frac{\partial h}{\partial t}+\frac{\partial h U_{x}}{\partial x}+\frac{\partial\left(h U_{y}\right)}{\partial y}=0 \\
\frac{\partial\left(h U_{x}\right)}{\partial t}+\frac{\partial}{\partial x}\left(h U_{x}^{2}+g \frac{h^{2}}{2}\right)+\frac{\partial}{\partial y}\left(h U_{x} U_{y}\right)= \\
-g h \frac{\partial Z_{b}}{\partial x}+\frac{\partial \tau_{s, x}}{\rho}-\frac{\partial \tau_{b, x}}{\rho}+\frac{\partial}{\partial x}\left(h v_{t} \frac{\partial U_{x}}{\partial x}\right)+\frac{\partial}{\partial y}\left(h v_{t} \frac{\partial U_{x}}{\partial y}\right) \\
\frac{\partial\left(h U_{y}\right)}{\partial t}+\frac{\partial}{\partial x}\left(h U_{y}^{2}+g \frac{h^{2}}{2}\right)+\frac{\partial}{\partial y}\left(h U_{x} U_{y}\right)= \\
-g h \frac{\partial Z_{b}}{\partial y}+\frac{\partial \tau_{s, y}}{\rho}-\frac{\partial \tau_{b, y}}{\rho}+\frac{\partial}{\partial x}\left(h v_{t} \frac{\partial U_{y}}{\partial x}\right)+\frac{\partial}{\partial y}\left(h v_{t} \frac{\partial U_{y}}{\partial y}\right)
\end{array}\right.
$$

The friction between the water and the bottom of the channel is an important parameter to model the hydrodynamics of flows in different applications. This parameter is modelled by means of the known Manning's formula (equation (2)) that relates the Manning's coefficient associated to different land uses $(n)$ with a friction coefficient $C_{f}$.

$$
C_{f}=g \frac{n^{2}}{h^{1 / 3}}
$$

The land uses and the associated Manning's coefficients defined for the study area were assigned using a tool implemented in Iber. Figure 4 shows the land uses assigned for this study. The Manning's coefficients of these land uses, that is, river, dense vegetation and residential, are 0.025 $\mathrm{s} / \mathrm{m}^{1 / 3}, 0.018 \mathrm{~s} / \mathrm{m}^{1 / 3}$ and $0.15 \mathrm{~s} / \mathrm{m}^{1 / 3}$, respectively. The area defined as "residential" corresponds with area of "Aquis Querquennis". 


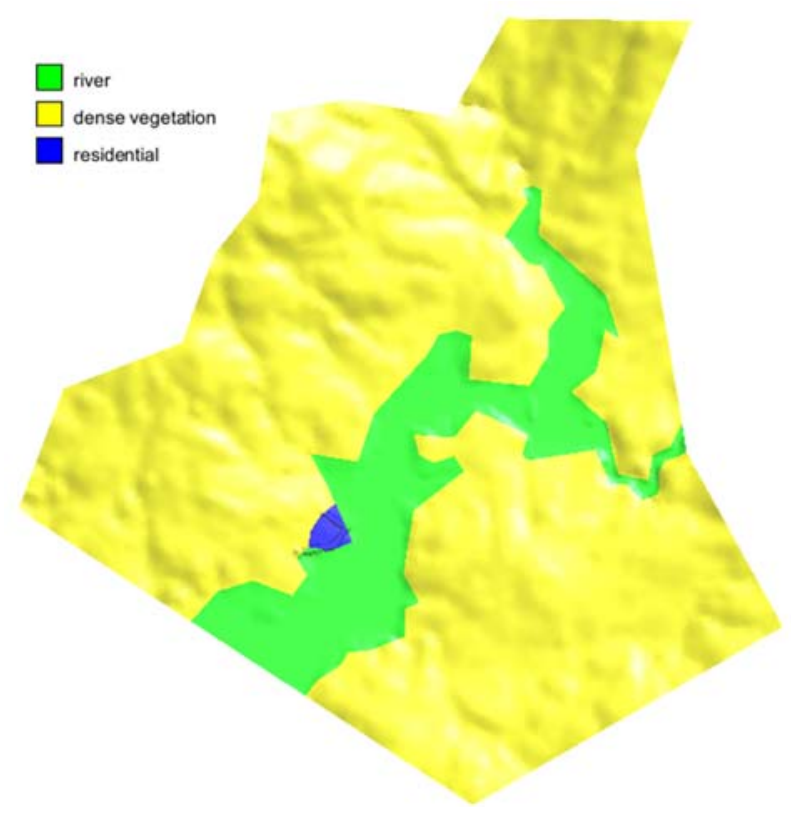

Figure 4. Land uses defined in the numerical domain defined for the analysis of the flooding of "Aquis Querquennis".

The numerical domain was discretized with an unstructured mesh using triangles with a characteristic length ranging from 5 to 30 meters. In figure 5 a detail of the mesh defined in the area of the Camp is shown.

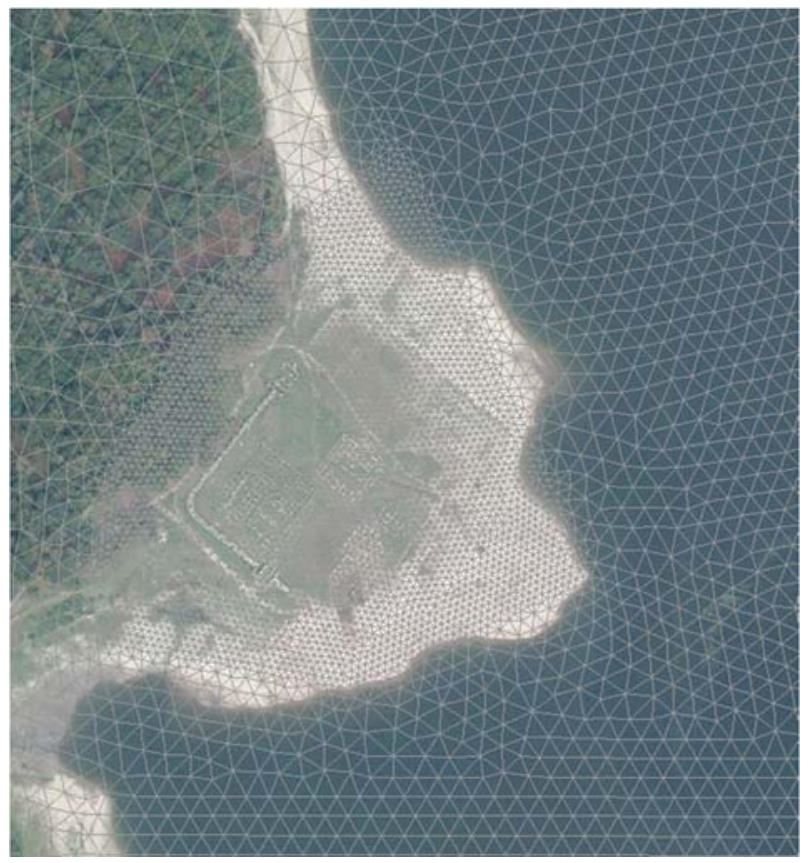

Figure 5. Detail of the mesh defined in the area near the Roman Camp "Aquis Querquennis".

A series of inflows associated to different return periods were analysed as inlet boundary condition. These inflows were obtained using the Gumbel's method [11] starting from the annual historical flow records over the last 27 years measured at the control station of "Ponte Liñares" (15 $\mathrm{km}$ upstream of "Aquis Querquennis"). The values of the inflows and its associated return periods are shown in table 1. An inflow correspondent to the design outflow of the spillway of the dam is 
The 1st International Electronic Conference on Hydrological Cycle (CHyCle-2017), 12 - 16 November 2017;

Sciforum Electronic Conference Series, Vol. 1, 2017

also analysed. The outflow was defined downstream the Roman Camp. Two values of water elevation were defined as initial condition, namely 549 m.a.s.l. and 543 m.a.s.l. Figure 6 shows a schematic view of the configuration of the defined numerical domain.

Table 1. Inflows obtained the Gumbel's method.

\begin{tabular}{cc}
\hline $\begin{array}{c}\text { Return period } \\
\text { (years) }\end{array}$ & $\begin{array}{c}\text { Inflow } \\
\left(\mathbf{m}^{3} / \mathbf{s}\right)\end{array}$ \\
\hline 1.5 & 44.2 \\
20 & 125.4 \\
50 & 150.1 \\
100 & 168.6 \\
500 & 211.3 \\
1000 & 229.7 \\
\hline
\end{tabular}

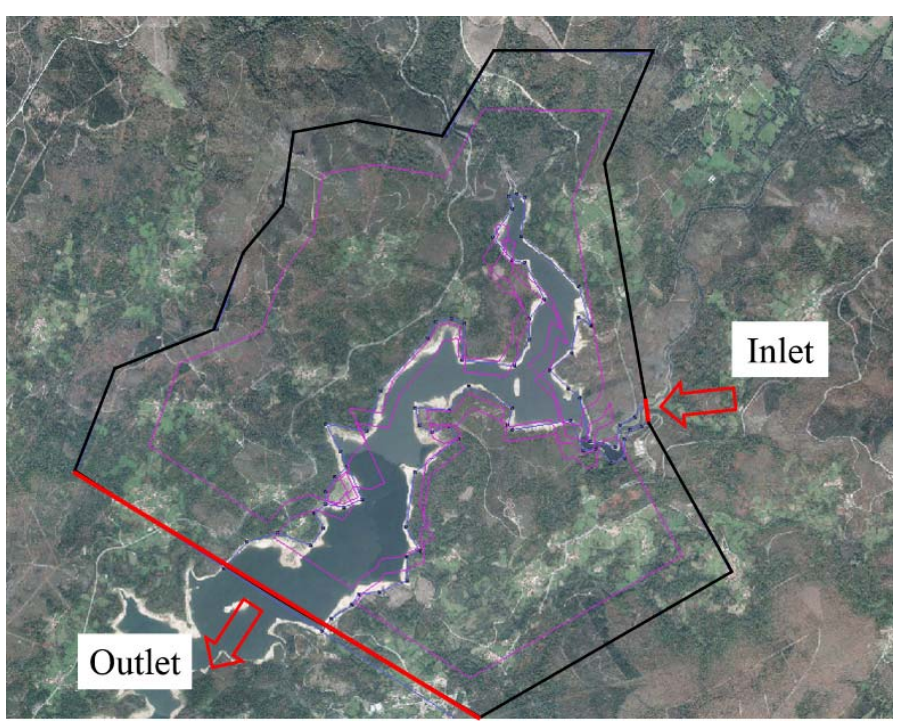

Figure 6. Numerical domain and boundary conditions defined for the analysed cases.

The topography of the study area was obtained from raster files obtained from the IGN (Instituto Geográfico Nacional, Gobierno de España) and the original bathymetry of the impoundment was reconstructed starting from old topographic maps of the area also obtained from IGN. From these topographic maps and using the code QGIS [12] we compute the original shape of the valley.

\section{Results and discussion}

In figure 7 the water depth near the Roman Camp obtained with an initial water elevation equal to the maximum water elevation of the impoundment (549 m.a.s.l.) is shown. 


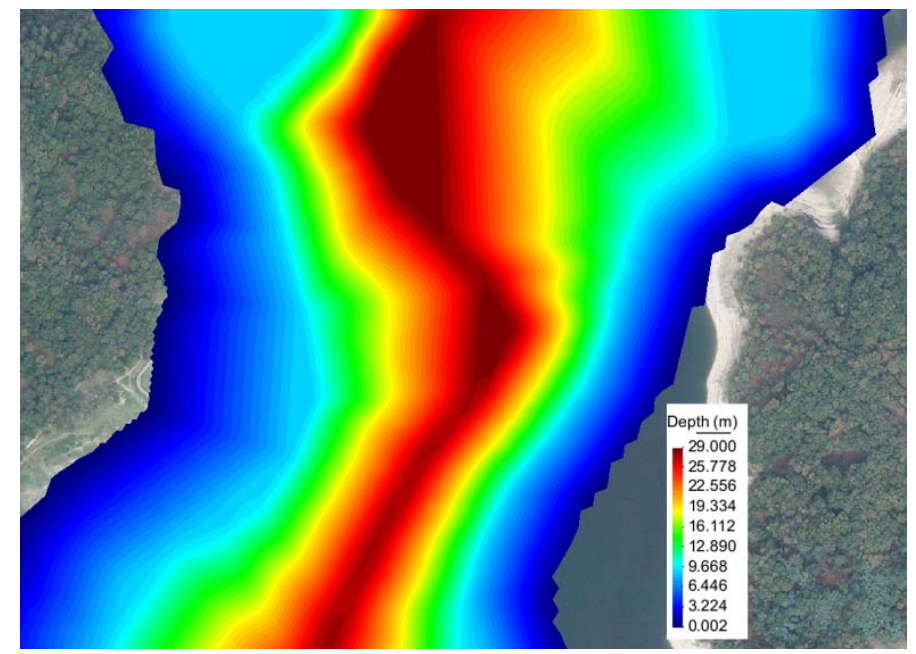

Figure 7. Water depth near “Aquis Querquennis" for an initial water elevation equal to 549 m.a.s.l.

Figure 7 shows that when the impoundment is at the maximum capacity (water elevation equal to 549 m.a.s.l.) the Roman Camp "Aquis Querquennis" is totally flooded. This is corroborated in past episodes of flooding. In order to avoid this situation two measures were implemented: first, the maximum water elevation of the impoundment was reduced to a value of 543 m.a.s.l. and, second, two mechanical barriers with a height of 545 m.a.s.l. were installed near the area of the roman Camp. Figure 8 shows the elevation of the terrain including the barriers and the results of the water depth for a initial water elevation equal to 543 m.a.s.l..
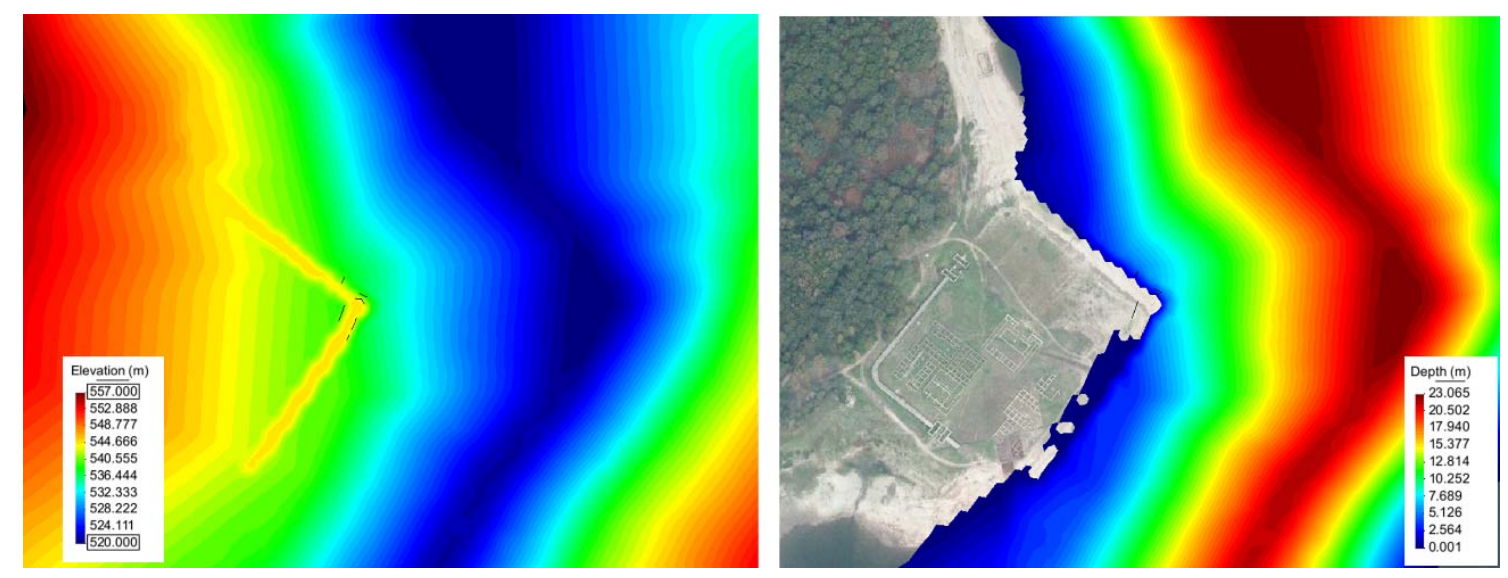

Figure 8. Elevation of the terrain in the area of the Roman Camp of Aquis Querquennis including the barriers (left panel) and water depth (right panel) for an initial water elevation equal to 543 m.a.s.l.

Figure 8 shows that for an initial water elevation equal to 543 m.a.s.l. and using the mechanical barriers to retain the water flow, the roman Camp is not flooded. Starting from this configuration a series of five values of inflow corresponding to five return periods (table 1) and the maximum expected flow of the dam were analysed. Figure 9 shows the results of water depth obtained for the simulation carried out using the maximum expected flow as the inflow condition. 
The 1st International Electronic Conference on Hydrological Cycle (CHyCle-2017), 12 - 16 November 2017; Sciforum Electronic Conference Series, Vol. 1, 2017
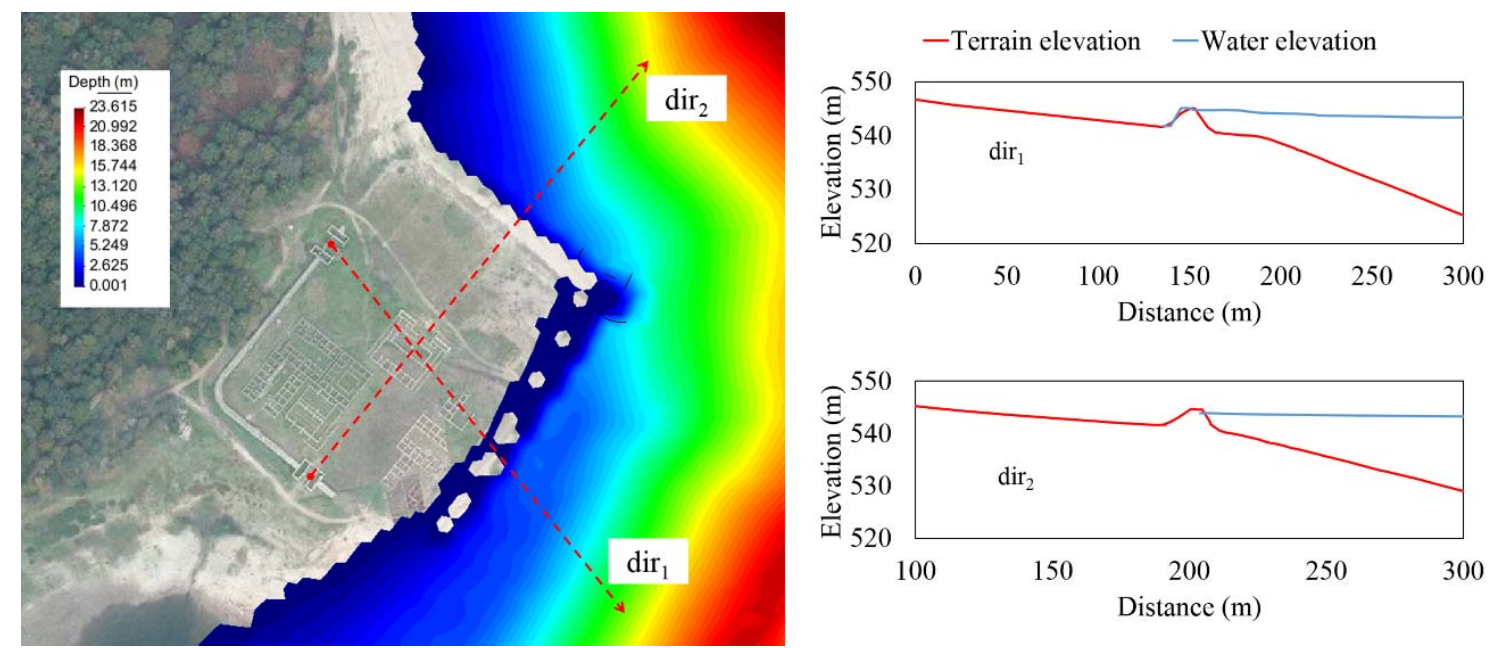

Figure 9. Maximum water depth near Aquis Querquennis obtained for the maximum expected flow (left panel) and profiles of the terrain elevation and the maximum water elevation obtained in two different directions (right panel).

Figure 9 shows that using the mechanical barriers and even for the maximum expected flow of the dam the maximum water elevation is less than the elevation of the barriers. Therefore, the Roman Camp "Aquis Querquennis" is protected against floods. The rest of analysed inflow conditions show the same behaviour.

\section{Conclusions}

In this work an application of the numerical code Iber to protect the historical cultural asset "Aquis Querquennis" against a series of floods corresponding to five return periods and the maximum expected flow of the dam associated to "Las Conchas" impoundment was shown. The flows corresponding to the analysed return periods were obtained starting from historical river flow records over the last 27 years measured at a control station near the area of study and using the Gumbel's method. The maximum expected flow of the dam was obtained from the technical specifications of the dam.

Results show that for the maximum water elevation of the dam (549 m.a.s.l.) the Roman Camp of Aquis Querquennis is flooded. To avoid this situation the installation of two mechanical barriers and the reduction of the maximum water depth to 543 m.a.s.l. is proposed. The results obtained with this new configuration shows that the Roman Camp "Aquis Querquennis" is protected against floods. Therefore, Iber is shown as valuable tool to analyse the effects of flooding on historical assets.

Acknowledgments: This work is partially supported under projects IMDROFLOOD (Water JPI - WaterWorks 2014), and Programa de Consolidación e Estructuración de Unidades de Investigación Competitivas (ED431C 2017/64 co-funded by European Regional Development Fund (FEDER).) and Risc_ML (Interreg Program, European Regional Development Fund, ERDF).

Author Contributions: J. González-Cao, O. García-Feal and M. Gómez-Gesteira conceived and designed this work. J. González-Cao and O. García-Feal carried out the numerical simulations. L. Cea and M. Gómez-Gesteira analysed the results. J. González-Cao, O. García-Feal, L. Cea and M. Gómez-Gesteira wrote the paper.

Conflicts of Interest: The authors declare no conflict of interest. The founding sponsors had no role in the design of the study, in the collection, analyses and interpretation of data, in writing of the manuscript and in the decision to publish the results.

\section{Abbreviations}

GEAMA: Grupo de Enxeñeria da Auga e do Medio Ambiente IGN: Instituto Geográfico Nacional 
The 1st International Electronic Conference on Hydrological Cycle (CHyCle-2017), 12 - 16 November 2017;

Sciforum Electronic Conference Series, Vol. 1, 2017

m.a.s.l.: meters above sea level

A.C.: After Christ

NW: North West

FEDER: Fondo Europeo de Desarrollo Regional

ERDF: European Regional Development Fund

\section{References}

1. I.E.G. Available on line: http://www.worldbank.org/ieg (accessed on 25/10/2017).

2. Drdácký, M.; Binda, L.; Herle, I.; Lanza, L.G.; Maxwell, I.; Pospísil, S. Protecting the cultural heritage from natural disaters; Policy Department Structural and Cohesion Policies: Culture and Education; Brussels, European Parliament, 2007.

3. Thieken, A.H.; Brito, J.-M.; Blanchais, J.M.; Morris, K.; Vlahov, M.; ten Brinke, W.B.W. Flood Mission Bulgaria 25th to 29th July 2005, Final Report, EU Member States Experts - GFZ Postdam (Germany), Centre national des Ponts de Secours (France), BCEOM (France/Bulgaria), Environmental Agency (UK), Ministry of Transport, Public Works and Water Management (The Netherlands), 2005.

4. Taboroff, J. The World Bank and ProVention - International Disaster Relief and Protection of Cultural Heritage, CRM, No.8, 2001, pp. 30-32.

5. Jirásek, P. Natural Disaster Cooperation and Solution (Floods in Prague 2002), in International Symposium Proceedings Cultural Heritage Disaster Preparedness and Response, Salar Jung Museum, Hyderabad, India, 23-27, November 2003, pp. 53-63.

6. SNCZI- Inventario de Presas y Embalses. Available online: http://sig.mapama.es/snczi/ (accessed on 24/10/2017). http://iberaula.es/web/index.php.

7. Bladé, E.; Cea, L.; Corestein, G.; Escolano, E.; Puertas, J.; Vázquez-Cendón, E.; Dolz, J.; Coll, A. Iber: Herramienta de simulación numérica del flujo en ríos. Revista Internacional de Métodos Numéricos para Cálculo y Diseño en Ingeniería, 2014, vol. 30(1), pp. 1-10.

8. Iberaula. Available online: http://iberaula.es/web/index.php (accessed on 24/10/2017).

9. Bonasia, R.; Areu-Rangel, O.S.; Tolentino, D.; Mendoza-Sanchez, I.; González-Cao, J.; Klapp, J. Flooding hazard assessment at Tulancigo (Hidalgo, Mexico). Journal of Flood Risk Management 2017, DOI: 10.1111/jfr3.12312.

10. Areu-Rangel, O.S.; González-Cao, J.; Crespo, A.J.C.; Bonasia, R. Numerical modelling of hydrological safety assignement in dams with IBER. Sustainable Water Resources Management 2017, DOI 10.1007/s40899-0170135-2.

11. Anderson, W.; Armstrong, W.; Armstrong, R.; et al. Chapter 5: Stream Hydrology. In Book Part 654 Stream Restoration Design National Engineering Handbook, United States Department of Agriculture, Natural Resources Conservation Service, USA, 2007.

12. QGIS Development Team. QGIS Geographic Information System. Open Source Geospatial Foundation Project. 2016

(C) 2017 by the authors; licensee MDPI, Basel, Switzerland. This article is an open access article distributed under the terms and conditions of the Creative Commons by Attribution (CC-BY) license (http://creativecommons.org/licenses/by/4.0/). 